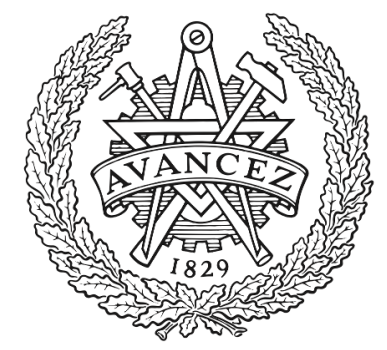

CHALMERS

UNIVERSITY OF TECHNOLOGY

\title{
The Emergence and Growth of Materials Science in Swedish Universities
}

Downloaded from: https://research.chalmers.se, 2023-04-26 12:01 UTC

Citation for the original published paper (version of record):

Gribbe, J., Hallonsten, O. (2017). The Emergence and Growth of Materials Science in Swedish Universities. Historical Studies in the Natural Sciences, 47(4): 459-493.

http://dx.doi.org/10.1525/hsns.2017.47.4.459

N.B. When citing this work, cite the original published paper. 


\title{
The Emergence and Growth of Materials Science in Swedish Universities
}

\begin{abstract}
The cross-disciplinary field of materials science emerged and grew to prominence in the second half of the twentieth century, drawing theoretical and experimental strength from the rapid progress in several natural sciences disciplines and connecting to many industrial applications. In this article, we chronicle and analyze how materials science established itself in Swedish universities in the 1960s and after. We build on previous historical accounts of the growth of materials science elsewhere, especially in the United States, and the conceptual guidance that these studies offer. We account for the emergence and growth of materials science in Sweden from the early influences brought back by academics from postdoc stays
\end{abstract}

*Gribbe: Department of Technology Management and Economics, Chalmers University of Technology, SE-4I2 96 Gothenburg, Sweden; gribbe@chalmers.se; Hallonsten: Lund University School of Economics and Management, P.O. Box 7080, SE-22007 Lund, Sweden; Olof.Hallonsten@fek.lu.se.

The following abbreviations are used: AFM, atomic force microscopy; ARPA, Advanced Research Projects Agency; DOD, U.S. Department of Defense; FRN, Forskningsrådsnämnden (Swedish Council for Planning and Coordination of Research); GSL, General Sciences Laboratory; HSNS, Historical Studies in the Natural Sciences; IDL, interdisciplinary laboratories; IM, Institutet för Mikrovågsteknik (Institute of Microwave Technology); IVA, Ingenjörsvetenskapsakademien (Royal Academy of Engineering Sciences); KTH, Kungliga Tekniska Högskolan (KTH Royal Institute of Technology); LEED, low-energy electron diffraction; MIT, Massachusetts Institute of Technology; NFR, Naturvetenskapliga Forskningsrådet (Swedish Natural Science Research Council); NMP, Nationella Mikroelektronikprogrammet (Swedish National Microelectronics Program); NSF, National Science Foundation; NUTEK, Närings- och Teknikutvecklingsverket (Swedish Business Development Agency); SLAC, Stanford Linear Accelerator Center; SRA, strategic research area; SSF, Stiftelsen för Strategisk Forskning (Swedish Foundation for Strategic Research); STM, scanning tunneling microscopy; STU, Styrelsen för Teknisk Utveckling (Board of Technical Development); TFR, Tekniska Forskningsrådet (Swedish Technical Research Council); Vinnova, Verket för Innovationssystem (Swedish Agency for Innovation Systems); Xerox PARC, Xerox Palo Alto Research Center.

Historical Studies in the Natural Sciences, Vol. 47, Number 4, pps. 459-493. ISSN 1939-I8II, electronic ISSN 1939-182X. (C) 2017 by the Regents of the University of California. All rights reserved. Please direct all requests for permission to photocopy or reproduce article content through the University of California Press's Reprints and Permissions web page, http://www. ucpress.edu/journals.php?p=reprints. DOI: https://doi.org/Io.I525/hsns.20I7.47.4.459. 
in the United States, through the creation of the first funding programs in the late 1970s, to the breakthrough of materials science in Sweden in the 1990s and its growth to a true area of strength and priority in Swedish science today. In line with previous studies, we highlight the role of funding agencies, providing the means for new cross-disciplinary activities across and between traditional disciplinary structures, and the role of new instrumentation, providing new experimental opportunities and uniting disciplinarily disparate research activities around common goals, as crucial in the process. Also, the role of entrepreneurially minded individuals is evident in the story: materials science was developed in Sweden largely by a new generation of scientists who established new activities within existing organizational structures, and thus accomplished long-term institutional change in a well-established field and system.

KEY WORDS: materials science, Sweden, nanotechnology, academic science, instrumentation, research funding

Materials science is a cross-disciplinary research field with roots in several classic natural sciences disciplines and strong links to applications in several commercially relevant areas of technological development. It emerged in the mid-twentieth century through the recombination of scientific ambitions and experimental opportunities, foremost in physics, chemistry, metallurgy, and engineering. In Swedish universities, the first traces of materials science are seen in the early I960s, and a decade later the name "materials science" was being used as a novel, cross-disciplinary scientific identity among some Swedish academic scientists. Since the early- to mid-I970s, materials science has gradually grown to become an area of strength of Swedish science. Given not least the current launch of the major research facilities the European Spallation Source for neutron scattering and the synchrotron radiation facility MAX IV in Lund, it seems materials science will remain a prioritized area in Swedish science and science policy for several decades to come.

In this article, we chronicle and analyze the emergence and growth of materials science in Swedish universities, with the help of some analytical tools from the sociology of science, and with inspiration from the history of materials science in the United States and elsewhere. ${ }^{1}$ Partly in line with these studies,

I. Bernadette Bensaude-Vincent, "The construction of a discipline: Materials science in the United States," Historical Studies in the Physical and Biological Sciences 3I, no. 2 (200I): 223-48; Bernadette Bensaude-Vincent, "Building Multidisciplinary Research Fields: The Cases of Materials Science, Nanotechnology and Synthetic Biology," in The Local Configuration of New 
and based on our extensive source material, we identify three key themes in the historical process under study: first, the pursuit of new research topics by entrepreneurially minded scientists, who established new cross-disciplinary research activities partly in spite of strong tradition and the hierarchies of existing university structures; second, the active role of third-party funding agencies that supported new research efforts outside of existing structures, and launched new comprehensive funding programs, thus enabling the formation and consolidation of materials science in Sweden; third, the role of technological developments in instrumentation and laboratory resources in driving the progress of materials science forward and unifying disciplinary disparate research activities. These three drivers of change-individuals, funding opportunities, and new instrumentation-coproduced what sociologists call institutional change, a long-term process whereby an organizational field (here, universities) and social system (here, the sciences) are altered in some parts, and/or new entities are formed within them, while the field and system remain largely intact.

The article connects to the state of the art in the history of materials science and focuses on an area of strength for Swedish science that has so far attracted only scarce and scattered scholarly attention. Thereby, it has a threefold purpose and relevance: (I) It adds a previously understudied case to the international body of literature on the history of materials science and recent science history in general. (2) It explains how materials science in Sweden was a product of its time, corresponding to renewed science policy priorities and structural transformations in science and society. (3) It provides an illustrated case of import of intellectual goods and technology from the

Research Fields, ed. Martina Merz and Pierre Sormani (Heidelberg: Springer, 2016); Emanuel Bertrand and Bernadette Bensaude-Vincent, "Materials Research in France: A Short-lived National Initiative (1982-1994)," Minerva 49, no. 2 (20II): 19I-2I4; Robert Cahn, The Coming of Materials Science (Amsterdam: Pergamon, 200I); Joseph D. Martin, "What's in a Name Change? Solid State Physics, Condensed Matter Physics, and Materials Science," Physics in Perspective I7 (2015): 3-32; Hyungsub Choi and Cyrus Mody, "The Long History of Molecular Electronics: Microelectronics Origins of Nanotechnology," Social Studies of Science 39, no. I (2009): II-50; Cyrus Mody, "Corporations, Universities, and Instrumental Communities: Commercializing Probe Microscopy, I98I-1996," Technology and Culture 47 (2006): 56-80; Cyrus Mody, Instrumental Community: Probe Microscopy and the Path to Nanotechnology (Cambridge, MA: MIT Press, 20II); Cyrus Mody and Hyungsub Choi, "From Materials Science to Nanotechnology: Interdisciplinary Center Programs at Cornell University, I960-200o," HSNS 43, no. 2 (2013): I2I-6I; Spencer Weart, "The Solid Community," in Out of the Crystal Maze: Chapters from The History of Solid State Physics, ed. Lillian Hoddeson, Ernst Braun, Jurgen Teichmann, and Spencer Weart (New York: Oxford University Press, 1992). 
United States to (Western) Europe in the Cold War context. Thus the article contributes to the international scholarly study of how and why new crossdisciplinary entities are formed in science, and provides insight into the specific institutional and political conditions of a small country's research system, and how these influence processes of renewal. Besides secondary literature, the analysis is based on two types of primary sources: printed material (reports, investigations) and interviews with researchers at the universities, in some of the industry research institutes, and at funding agencies. A total of 34 interviews were conducted as part of the work, of which 14 have been used for this article.

\section{HISTORICAL AND CONCEPTUAL STARTING POINTS}

Classic views on the progress of science hold that the development and refinement of new theory is its main driving force. ${ }^{2}$ Following the lead of several historians and sociologists of science, we reject this view and conceptualize the emergence and growth of materials science, in Sweden and elsewhere, as driven mostly by the proliferation of new instrumentation, the entrepreneurial spirit of individual scientists, and (strategic) funding programs.

To a significant degree, the progress in instrument development has set the framework for the evolution of materials science and has steered the direction of research activities. Among the most notable advances were x-ray diffraction and the transmission electron microscope in the 1950s, enhancement of synchrotron radiation and neutron scattering technologies to the benefit of several spectroscopic and crystallographic techniques in the 1960s and on, improvements in vacuum technology in the 1970s, and the introduction of the scanning tunneling microscope (STM) and atomic force microscope (AFM) in the I980s and 1990s. ${ }^{3}$ This continuous instrument development has not only opened new research opportunities but also contributed strongly to the formation of scientific communities by the use of common laboratory resources that unify otherwise disparate research activities and provide a physically very palpable common denominator. "Generic instruments"- that is, instruments invented for one purpose but subsequently used for others- have been proven to have a key function in the progress of science, and materials science is filled

2. Karl Popper, The logic of scientific discovery (London, New York: Hutchinson, 1959); Thomas Kuhn, The structure of scientific revolutions (Chicago: University of Chicago Press, 1962).

3. Bensaude-Vincent, "The construction" (ref. I), 225. 
with them. ${ }^{4}$ Meanwhile, the significant diversity of techniques and instrumentation used has contributed to making materials science an amorphous and varied entity that evades most disciplinary classification, but that gains strength over time by its close connections to applications and thus strategic importance, which shows in the key role of research policy and funding programs to unite and provide the necessary means for coherent advance in the field as a whole.

Although the history of materials science in Sweden has received only scarce scholarly attention, there is a rich international literature on the history of its counterpart in the United States. As a cross-disciplinary field within the natural and technical sciences, materials science emerged in the United States as an engineering sub-specialty with growing influences from the natural sciences. The term "materials science" became increasingly common in U.S. universities in the late 1950s, in departmental names and curricula, although there was never any complete coherence in the use of disciplinary labels among those active in the field and adjacent areas of physics, chemistry, and metallurgy. ${ }^{5}$ Importantly, materials science was not the product of specialization within a discipline (as was the case when nuclear and particle physics emerged in the 1950s, or organic and inorganic chemistry in the late nineteenth century), but rather the result of researchers from different disciplines gathering around a common interest in the structures and characteristics of materials, and some common interests in making use of advanced new instrumentation for experimental work to study these. ${ }^{6}$ Parallel developments in solid state physics contributed with deeper theoretical knowledge, and cross-disciplinary $R \& D$ efforts in the private sector forged important alliances with academic departments and launched laboratories and research efforts beyond immediate industrial applications, which attracted important political attention as the demand grew for new materials for military applications. ${ }^{7}$ The work to anchor materials science in the forefront of physics research, including quantum mechanics, was countered by technical restrictions that seem to have forced the research efforts in a more pragmatic direction, where disciplinary and sectorial boundaries

4. Bernward Joerges and Terry Shinn, Instrumentation Between Science, State and Industry (Berlin: Kluwer Academic Publishers, 20oI); Terry Shinn and Bernward Joerges, "The transverse science and technology culture: dynamics and roles of research technology," Social Science Information 4I, no. 2 (2002): 207-5I.

5. Cahn, The Coming (ref. I), 4; Martin, "Name Change" (ref. I).

6. Bensaude-Vincent, "The construction" (ref. I), 224.

7. Ibid., 226-27. 
mattered little and the common interest in the structures and characteristics of various materials dominated: materials science and materials technology were closely related, and academic, commercial, and military interests often combined within organizational entities and research lines. ${ }^{8}$

Funding agencies that had a hybrid mandate of supporting academic research with clear practical relevance played important roles in the growth of materials science in the United States. ${ }^{9}$ Funding for science was generous in the early Cold War era, and government steering was minimal, but the sciences were also gradually tied closer to societal needs, including both military and industrial applications. ${ }^{10}$ Early on, military interests in advanced materials for weapons technologies and space exploration programs were important motivators for political initiatives in the field. Later, as the Cold War wound down and new priorities emerged and took root, materials scientists benefitted from the proven applicability of their field, when the importance of research on materials for meeting society's grand challenges, as well as the needs for revitalization of large industrial sectors, provoked an active role of science policy and funding actors and organizations in the field. ${ }^{11}$ Cross-disciplinary research programs and research centers that run across existing academic and industrial organizational structures have been important in materials science, and the model has also spread to other areas in recent decades. The dependence on advanced and costly instrumentation has further necessitated broad programs with a different funding structure than the classic academic model. Not only did the Sputnik crisis lead to a tripling of the U.S. federal R\&D expenditures in a mere decade (1958-1968), it also brought the first reevaluation of the science policy doctrine of generous funding and little or no steering that had ruled since the end of World War II, and the introduction of some strategic prioritization on behalf of ministries and agencies with research funding portfolios. ${ }^{12}$

8. Mody and Choi, "From Materials Science" (ref. I), I26-27; Martin, "Name Change" (ref. I).

9. Bensaude-Vincent, "The construction" (ref. I); Mody and Choi, "From Materials Science" (ref. I).

Io. Daniel S. Greenberg, The Politics of Pure Science, 2nd ed. (Chicago: The University of Chicago Press, 1967/1999), 5I-52; David Kaiser, "The Postwar Suburbanization of American Physics," American Quarterly 56, no. 4 (2004): 85I-88.

II. Philip Mirowski and Esther-Miriam Sent, Science Bought and Sold: Essays in the Economics of Science. (Chicago: University of Chicago Press, 2002); Olof Hallonsten, Big Science Transformed: Science, Politics and Organization in Europe and the United States (Basingstoke, U.K.: Palgrave Macmillan, 20I6); Mody and Choi, "From Materials Science" (ref. I), I43.

12. Bruce Smith, American Science Policy since World War II (Washington, DC: Brookings Institution Press, 1990), II3. 
Materials science was among the first beneficiaries of this changed attitude, as exemplified by the twelve Interdisciplinary Laboratories (IDLs) for materials science created on university campuses across the United States in 196I, under the DOD's Advanced Research Projects Agency (ARPA). In 1972, the IDLs were transferred to the National Science Foundation (NSF), and their names changed to Materials Research Laboratories. ${ }^{13}$

The reorientation of research policy that began in most Western countries in the 1960s with a profound reevaluation of priorities, was accentuated by the economic downturn in the 1970s, and even more deeply felt beginning in the 1980s, when technology transfer and not least (commercial or social) relevance of publicly funded R\&D was regulated and implemented in many governmental science funding programs and policy schemes. ${ }^{14}$ Another consequence of this reorientation was reform to public R\&D funding that let unfettered money stand back (in relative terms) in favor of resources directed to specific areas or to $\mathrm{R} \& \mathrm{D}$ with specific aims (such as commercialization or internationalization). Materials science is certainly not the only area of science that was boosted by these policy developments, but it is a clear example. European universities are comparable rigid and conservative organizations, although in Sweden they have been subject to far-reaching deregulation, and while they provide a stable institutional context where creativity can thrive, they are also difficult to change, which paradoxically enough might work counterproductively to necessary longterm intellectual renewal. ${ }^{15}$ Third-party funding has therefore a role to play in the development of science, both as strategic funding programs directed to specific disciplines or problem areas, and as the general project grant funding awarded purely on basis of scientific merit, which may allow researchers at various career stages to develop and try new approaches

I3. Mody and Choi, "From Materials Science" (ref. I), I27.

I4. Smith, American Science Policy (ref. I2), 70-72; John Irvine and Ben Martin, Foresight in Science: Picking the Winners (London: Pinter, 1984); Elizabeth Popp Berman, "Not Just Neoliberalism: Economization in US Science and Technology Policy," Science, Technology, \& Human Values 39, no. 3 (2014): 397-43I.

I5. On the differences between European (German) and American academic traditions: Burton Clark, Places of inquiry: Research and advanced education in modern universities (Berkeley: University of California Press, 1995); Paul Trowler, Academics responding to change: New higher education frameworks and academic cultures (Buckingham, U.K.: Open University Press, 1998). On Swedish academia and its recent deregulation: Mats Benner, Kunskapsnation i kris? Politik, pengar och makt $i$ svensk forskning (Stockholm: Nya Doxa, 2008). 
outside of, or independent of, established structures and authorities in their fields. ${ }^{16}$

Although the history of science is often written from a macro perspective, to demonstrate relevance and tie the chronicled developments to historical processes and events in society at large, there is also a strong tradition of focusing on the deliberations and actions of individuals in historical studies of science. ${ }^{17}$ Theoretically, the bridging of micro and macro levels means finding "microfoundations" of institutional change, and combining the concept of entrepreneurial behavior and skills with institutional analysis and long-term, macro-level analyses. ${ }^{18}$ The key question is then how and why micro-level deliberations and actions aggregate to produce broader and higher-level change, or in this specific case, how professional scientific work on an individual level interleaves with technological development and policymaking to produce the growth of a new cross-disciplinary field like materials science in a comparably rigid and conservative organizational and institutional context, like the Swedish university system. This is what sociologists call institutional change: the framework is intact, but important elements have been added and altered. ${ }^{19}$ The history of science has convincingly shown that such change typically happens gradually and incrementally, most often from within and on basis of existing elements, and by the work of the curious, inspired, hard-working, entrepreneurial individual who is ready to act on opportunity and promote the use of a new instrument, form

I6. Dietmar Braun, "The role of funding agencies in the cognitive development of science," Research Policy 27 (1998): 807-2I; Paula Stephan, How Economics Shapes Science (Cambridge, MA: Harvard University Press, 20I2), I29ff.

17. Olof Hallonsten, "The parasites: Synchrotron radiation at SLAC, 1972-1992," HSNS 45, no. 2 (2015): 217-72.

I8. Peter Hall, "Historical Institutionalism in Rationalist and Sociological Perspective," in Explaining Institutional Change: Ambiguity, Agency, and Power, ed. James Mahoney and Kathleen Thelen (Cambridge: Cambridge University Press, 2010); Julie Battilana, Bernard Leca, and Eva Boxenbaum, "How Actors Change Institutions: Towards a Theory of Institutional Entrepreneurship," The Academy of Management Annals 3 (2009): 65-I07; Royston Greenwood and Roy Suddaby, "Institutional entrepreneurship in mature fields: The Big Five accounting firms," Academy of Management Journal 49 (2006), 27-48.

19. Institutional change: Kathleen Thelen, How Institutions Evolve (Cambridge: Cambridge University Press, 2004). Institutional change in science: Thomas Heinze and Richard Münch, eds., Innovation in Science and Organizational Renewal: Historical and Sociological Perspectives (Basingstoke, U.K.: Palgrave Macmillan, 20I6); Steffi Heinecke, "The Gradual Transformation of the Polish Public Science System," PLoS ONE II, no. 4 (2016): eoI5326o; Olof Hallonsten and Thomas Heinze, "Formation and Expansion of a New Organizational Field in Experimental Science," Science and Public Policy 42, no. 6 (2015): 84I-54. 
a new type of (cross-disciplinary) collaboration, or obtain a new type of funding for a new type of effort. ${ }^{20}$

Another way of saying this is that scientific progress depends heavily on the exchange of ideas and human capital across institutional, disciplinary, and geographical borders. It is evident from our material and analysis that the import of instruments and experimental techniques, including knowhow, to Swedish studies in the I970s and beyond, by the work of entrepreneurially minded individuals, drove the early development of materials science in Sweden. More specifically, the transfer of knowledge from the United States to Sweden in the early I970s and on was a key factor for the initiation of the long-term development and institutional change that the article chronicles and analyzes. Of course, Swedish materials science was not imported from the United States into a vacuum. Research on materials took place in both academic and industrial sectors in Sweden long before the history accounted for in this article began, and one theme in the following will be to explore how the new materials science, starting to take root in the early I970s, related to existing $\mathrm{R} \& \mathrm{D}$ efforts in similar areas. But there is also a clear historical distinction to be made: the research on materials in Sweden prior to the I970s, which took place in industrial research institutes and technical universities and was mostly oriented toward the needs of the wood and iron industries, differs from the cross-disciplinary materials science that emerged and established itself gradually in Swedish universities in the I970s and after, by the proliferation of new instruments, the introduction of new funding programs, and the work of a new generation of entrepreneurially minded scientists.

\section{CHRONOLOGY OF THE EMERGENCE AND GROWTH OF MATERIALS SCIENCE IN SWEDISH UNIVERSITIES}

\section{The American Import, 1961-1976}

As noted in the previous section, the launch of graduate and undergraduate education programs in materials science in U.S. universities in the 1950s can be

20. Hallonsten, "The parasites" (ref. 17); Thomas Heinze, Olof Hallonsten, and Steffi Heinecke, "From Periphery to Center: Synchrotron Radiation at DESY, Part I: 1962-1977," HSNS 45, no. 3 (2015): 447-92; Michael Hilzik, Big Science: Ernest Lawrence and the Invention that Launched Military-Industrial Complex (New York: Simon \& Schuster, 2015); Robert Kohler, Lords of the Fly: Drosophila Genetics and the Experimental Life (Chicago: University of Chicago Press, 1985); Mody, Instrumental Community (ref. I). 
identified as the first breakthrough in the field, as it provided the crossdisciplinary activities some academic credibility. In 1969, a third of the departments of metallurgy in U.S. universities had added the words "materials science" to their name, and in Europe, a similar development occurred where broader educational programs under the new name were launched throughout the 196 os. $^{21}$

After the Sputnik Crisis, U.S. federal R\&D expenditure increased rapidly, and especially the DOD funded many activities in materials science. This close connection to the U.S. defense budget did not prevent international exchanges or a transfer of knowledge and technologies beyond the U.S. R\&D system; quite the opposite, the generally open and positive American attitude toward transatlantic research exchanges during the Cold War led to profound exchange between the U.S. materials science labs and emerging European research environments in the area. ${ }^{22}$ The Swedish-American relationships were generally good, and especially so within those disciplines that later contributed to the forming of a materials science field in Sweden.

The Swedish chemist and metallurgist Mats Hillert got his doctoral training at MIT between 1953 and 1956. With a background at the KTH Royal Institute of Technology in Stockholm (hereafter, KTH) and its internationally recognized advances in $\mathrm{x}$-ray crystallography on steel structures, Hillert had gotten one of many scholarships for KTH students to spend a year at MIT, after which he was offered a prolonged stay and a doctoral program. ${ }^{23} \mathrm{~A}$ few years after his return to Stockholm, in 196I, Hillert was appointed professor of metallography at $\mathrm{KTH} .{ }^{24}$ Under strong influence of his experiences in the United States, the full cycle of higher education in metallurgy at KTH was renewed and broadened, and several new doctoral candidates were recruited. ${ }^{25}$ In polymer science, Bengt Rånby played a similar role of establishing the new discipline at KTH, supported by a broad international network. Rånby received his doctoral training at Uppsala University and spent most of the

2I. Cahn, The Coming (ref. I), 4-7.

22. John Krige, American Hegemony and the Postwar Reconstruction of Science in Europe (Cambridge, MA: MIT Press, 2006), 9-I4.

23. John Ågren, "A short biography of Mats Hillert," in Thermodynamics and phase transformations: The selected works of Mats Hillert, ed. John Ågren, Yves Bréchet, and Christopher Hutchinson (Les Ulis, FR: EDP Sciences, 2006); Mats Hillert, interview with Johan Gribbe, I9 Oct 2015.

24. Torsten Althin, KTH 19I2-62: Kungl. Tekniska Högskolan i Stockholm under 50 àr (Stockholm: KTH, 1970), I33.

25. John Ågren, interview with Johan Gribbe, I4 Sep 20I5; Hillert interview (ref. 23). 
I950s in the United States, first at the Polytechnic Institute of Brooklyn and then as research scientist at American Viscose Corporation and research professor at the College of Forestry of the State University of New York, before being appointed professor at KTH in $196 \mathrm{I}^{26}$ In much the same way as Hillert in materials science and metallurgy, Rånby established new research and higher education programs based on his international experiences. ${ }^{27}$

An area that underwent a very swift development in the I960s and '70s was surface science - that is, the study of physical and chemical phenomena at the interface of two phases (solid, gas, liquid) of materials — which was closely connected to semiconductor physics and benefited strongly from the development of new methods and techniques for characterization of surfaces in the United States at the time. Most of all, the developments within ultrahighvacuum technology, enabling better purification of samples as well as enhancement of several varieties of spectroscopy and diffraction techniques, including low-energy electron diffraction (LEED), were key. Surface science had long been a field of strength in Sweden, and got a boost not least in Uppsala in the 1960s, by the work of Kai Siegbahn, professor of physics and Nobel laureate (physics, I98I) whose research produced the ESCA (electron spectroscopy for chemical analysis, now called $\mathrm{x}$-ray photoelectron spectroscopy, XPS) technique that became internationally renowned and widespread and whose use in surface science still constitutes a backbone of the physics research at Uppsala University. ${ }^{28}$ Several prominent Swedish researchers in surface science were trained in Uppsala in the 1960s, including Stig Lundqvist and Stig Hagström, who built influential research activities at Chalmers University of Technology in Gothenburg (hereafter, Chalmers) and Linköping University and furthered the field of materials science in Sweden largely by international influences and exchanges. ${ }^{29}$

Stig Lundqvist received his doctorate in Uppsala in 1955 and went on to a postdoctoral stay at the University of Pennsylvania, after which he got a position as research assistant and later professor (1963) of theoretical physics at Chalmers. With the help of his broad international network, which included

26. Ann Christine Albertsson and Otto Vogl, "In memoriam. Professor Bengt Rånby ( 5 April 1920-Io October 2000)," Journal of Polymer Science: Part A: Polymer Chemistry 39 (2000): 263-64.

27. Ann-Christine Albertsson, letter to Johan Gribbe, I3 Apr 2016.

28. Cahn, The Coming (ref. I), 404-08; Olof Hallonsten, "Growing Big Science in a Small Country," HSNS 4I, no. 2 (2OII): I79-2I5, on 2I2-I4.

29. Anders Flodström, interview with Johan Gribbe, 25 Sep 20I5; Bengt Lundqvist, interview with Johan Gribbe, 28 Oct 20I5; Jan-Eric Sundgren, interview with Johan Gribbe, 3 Nov 20I5. 
physicist and later Nobel laureate (physics, 1972) J. Robert Schrieffer at University of Pennsylvania, Lundqvist renewed the surface science activities at Chalmers and built an internationally recognized research environment with recurring exchanges not least with materials scientists in the United States. ${ }^{30}$ Chalmers also made heavy investments in electron microscopy at the time, and amassed the largest collection of instruments in this field in Scandinavia. Among the leading figures active at Chalmers at this time were Stig Andersson, who received his doctorate at Chalmers in 1970 and worked closely with North American colleagues on metal and semiconductor surfaces with LEED; Tord Claeson, who did research on superconductors at University of California at San Diego and built his own low-temperature laboratory at Chalmers upon his return in 1966; and condensed matter theorist Lars Hedin, who spent time at Argonne National Laboratory in Illinois after earning his doctoral degree in 1965. ${ }^{31}$ The wide geographical dispersal of the research environments in the United States visited by scientists from Chalmers reflects the well-established international networks of senior scientists at Chalmers in the 1960s, through which younger scholars came into contact with leading U.S. specialists within various fields of the emerging discipline of materials science.

Stig Hagström, also trained in Uppsala, was very influential in the development of materials science in Linköping, and had his own contacts and exchanges with leading U.S. research laboratories and universities. Between 1964 and 1966, Hagström worked with electron spectroscopy at MIT and Lawrence Berkeley National Laboratory in California, and became assistant professor at Chalmers upon his return to Sweden. ${ }^{32}$ In 1969, he was appointed professor of physics at the newly created Linköping Institute of Technology (which became Linköping University in 1975), where he assembled a materials science research group, at first comparably small-scale and in the Uppsala spectroscopy tradition, but soon with a growing importance of synchrotron radiation, a laboratory resource accidentally supplied at particle accelerator labs and available to the Linköping group through a collaboration with a newly established "parasitic" synchrotron radiation laboratory at the Stanford Linear Accelerator Center (SLAC). ${ }^{33}$ In the early 1970s, Stig Hagström did research on new materials for data storage at Stanford and the nearby Xerox Palo Alto

30. Lundqvist interview (ref. 29).

3I. Tord Claeson, interview with Johan Gribbe, 7 Oct 2015; Lundqvist interview (ref. 29).

32. Flodström interview (ref. 29).

33. Hallonsten, "The parasites" (ref. I7). 
Research Center (PARC), which had developed into a leading materials science center on the American West Coast. ${ }^{34}$ Several young researchers from Linköping with an interest in spectroscopy spent time at Stanford and Xerox PARC in the 1970s; among them was Anders Flodström, who later was very influential in the development of the Swedish synchrotron radiation source MAX-lab in Lund in the early 1980s. ${ }^{35}$ The international orientation of the growing materials science research activities in Linköping also enabled the recruitment of professor William Salaneck from Rochester, New York, who built a research group in the area of polymer research at Linköping University in the I970s and after. ${ }^{36}$

Another research line with close connections to surface science that was developed in Linköping during the I970s was thin film technology, which also required access to ultrahigh-vacuum technology. ${ }^{37}$ In 1975, Linköping University decided to assemble a research group in thin film technology as a means to develop surface physics further in the direction of industrial applications. Several doctoral students were recruited, and instrumentation was acquired. When in 1976, Stig Hagström moved to Stanford to take a position as research leader at Xerox PARC General Sciences Laboratory (GSL), he continued to work with the development of the thin film technology activities in Linköping. A collaboration between Linköping University and Northwestern University in Illinois also became very important for the further development of the activities in the 1980 s. ${ }^{38}$

\section{Ideas for New Funding Programs, 1978-1980}

Toward the end of the 1970s, some Swedish research funding agencies began to show considerable interest in advanced materials science, and it became a hot topic for investigations and studies that also led to new funding programs. In 1968, the Board of Technical Development (Styrelsen för Teknisk Utveckling, STU) had been formed by the merger of several research funding agencies, among them the Technical Research Council (Tekniska Forskningsrådet,

35. Hallonsten, "Growing Big Science" (ref. 28), 190.

36. Flodström interview (ref. 29).

37. Cahn, The Coming (ref. I): 4IO-II.

38. Sundgren interview (ref. 29); Flodström interview (ref. 29). 
TFR), as part of a collected governmental strategy to strengthen research policy and funding in the area of technical and industrially relevant sciences. ${ }^{39}$

Initially, the new funding agency largely followed in the paths of its predecessors, but there was also a lively discussion over its role in the research funding system, not least concerning whether it should be a tool for industrial policy or rather seek to bridge the academy-industry divide. ${ }^{40}$ A governmental investigation of the role and function of STU, launched in 1974, concluded that STU should take a more active role in the research system and seek to identify and support strategically important research areas. ${ }^{41}$ The result was a reorganization in which one member of the investigation committee, Sigvard Tomner, became the new director general, and the newly created planning unit got a special position as gatherer of intelligence and provider of knowledge both for the internal STU activities and for research policy planning on the national, governmental level. The efforts of STU in the university sector were to focus on framework programs aimed at academic research environments with industrial relevance, and Göran Friborg was recruited from the Natural Sciences Research Council (Naturvetenskapliga Forskningsrådet, NFR) to head these framework programs. ${ }^{42}$ In I978, the government issued a special request to STU to identify areas where Sweden could increase its international competitiveness through research and technical development, as part of an overall strategy to meet structural transformation of the economy and the effects of the international economic downturn. STU established tighter contacts with counterparts abroad, not least in Japan and the United States, and as a result of this work, materials science was identified as a appropriate area for new STU framework programs. ${ }^{43}$ In the fall of 1978, Björn Englund and Paul Forsgren from the STU planning unit traveled to the United States for a twoweek tour of several universities and industry R\&D labs. Their impressions from this trip would later have direct impact on the shape of the new framework programs within surface science that STU launched in I980 (see below).

39. Bo Persson, Motsträviga Myndigheter: Sektorsforskning och politisk styrning under 1980-talet (Stockholm: Nya Doxa, 200I), 85.

40. Ingemar Pettersson, Handslaget: Svensk Industriell Forskningspolitik 1940-1980 (Stockholm: KTH, 2013), I78-79; Hans Weinberger, Nätverksentreprenören (Stockholm: KTH, 1996), 432-34; Persson, Motsträviga (ref. 39): 85-86.

4I. Weinberger, Nätverksentreprenören (ref. 40), 4I7-20; Persson, Motsträviga (ref. 39), 9I; Lennart Stenberg, interview with Johan Gribbe, II Dec 20I5.

42. Persson, Motsträviga (ref. 39), 88; Stenberg interview (ref. 4I); Weinberger, Nätverksentreprenören (ref. 40), 4I7, 428, 438.

43. Weinberger, Nätverksentreprenören (ref. 40), 438-39. 
The tour was planned by the Swedish scientific-technical attaché in Washington, in collaboration with the U.S. National Materials Advisory Board. Among the industrial labs visited were Bethlehem Steel in Pennsylvania, Du Pont in Delaware, Ford Motor Company in Michigan, and Lockheed Palo Alto Research Laboratory and Douglas Aircraft Company in California. The delegation also visited several leading U.S. universities and their materials science centers, including the Center for Materials Science and Engineering at MIT, which was one of the eleven IDLs that had transferred from ARPA to NSF in 1972. The visit to Stanford University and the nearby Xerox PARC appears to have made an especially lasting impression on the delegation. This visit took place outside of the regular agenda and was most likely arranged directly with Stig Hagström (director of the Xerox PARC GSL since 1976), who was very active in strengthening the research on materials within solid state physics and electronics, with applications for information technology. ${ }^{44}$ At Stanford University, the delegation also visited the Department of Materials Science and Engineering, where Linköping University alumnus Birgit Jacobsson did research, funded by a special grant from STU, and the Stanford IDL Center for Materials Research, both of which were at the forefront of the applications of electron microscopy for a variety of materials science applications. ${ }^{45}$

The study trip by the STU delegation covered a broad spectrum of research specialties in the growing cross-disciplinary field of materials science, and gave the delegation a comprehensive view of the priorities of the increasingly noteworthy U.S. community of materials scientists, in academia and industry alike. Several of the areas of strength of the U.S. research environments visited later became foci for targeted Swedish investments in the 1980s, including composite materials, powder metallurgy, polymers, and superconductivity. But the highest priority of STU would be a new program in surface science.

\section{The Physics and Chemistry of Surfaces, 1980-1985}

When in April 1980, STU formally decided to create a framework program for surface science, the decision had been preceded by two years of careful investigation and deliberation within the organization and in contact and collaboration with several research groups in Swedish universities that had the potential to

44. Englund and Forsgren, Materialteknik (ref. 34).

45. Flodström interview (ref. 29); Sundgren interview (ref. 29); Englund and Forsgren, Materialteknik (ref. 34). 
eventually receive support from the program. Surface science had distinguished itself as an especially relevant and worthy field for a focused program, with clear industrial applications, enough scientific breadth, and an international flavor. Birgit Jacobsson had returned to Linköping from Stanford in 1979, and was immediately engaged in the planning of the program, and Stig Hagström also contributed with his experiences and knowledge about the industrial relevance of the area. In late 1979, a planning group was formed, including representatives from several industrial firms, the universities in Linköping and Lund, Chalmers in Gothenburg, the Institute for Surface Chemistry in Stockholm, as well as STU personnel. ${ }^{46}$

The planned framework program was to have two emphases: first, surface and colloid chemistry, which had a strong tradition in Swedish academia, especially in Lund and Stockholm; and second, surface physics, which was represented by several leading research environments. At Chalmers, the legacy of Stig Lundqvist had formed the basis of several thriving research groups, including one headed by Bengt Kasemo, who had cultivated a fruitful collaboration with the automotive company Volvo on catalytic conversion of exhaust gas, partly funded by STU. Kasemo subsequently represented Chalmers University of Technology in the planning group for the new framework program. ${ }^{47}$ In Linköping, the followers of Stig Hagström had managed to establish themselves as a leading Swedish group in surface physics, and another group around Ingemar Lundström had conducted complementary activities in surface science in the border area between physics, biology, and chemistry. ${ }^{48}$

Throughout the summer of 1980 , the details of the new program were laid out by the planning group, and in September of 1980 , a call was issued. Some thirty applications came in and were discussed by the steering group, which had been formed out of the previous planning group and consisted of scientists, administrators, and industry representatives. The balance between industrial and scientific relevance of the applications was an important part of the selection process. The final decision to fund ten research projects (see Table I)

46. Weinberger, Nätverksentreprenören (ref. 40), 44I-45; Persson, Motsträviga (ref. 39), 89.

47. Yt- och kolloidvetenskap i Sverige, STU-information 89-1978 (Stockholm: STU, 1978); Weinberger, Nätverksentreprenören (ref. 40), 44I-44; Materialforskning vid Chalmers tekniska högskola: Sammanställning över högskolans forskningsprojekt inom materialvetenskap (Göteborg: Chalmers University of Technology, I982), 9-I2, 2I; Bengt Kasemo, interview with Johan Gribbe 6 October 2015 .

48. Sundgren interview (ref. 29). Ingemar Lundström, interview with Johan Gribbe, $24 \mathrm{Sep}$ 2015 . 
TABLE 1. Projects granted funding with the STU framework program for the physics and chemistry of surfaces, 1980-1985.

\begin{tabular}{|c|c|c|}
\hline Project name & Department, university & Members \\
\hline $\begin{array}{l}\text { Surface modification of metallic } \\
\text { and polymer substrates } \\
\text { Structure and properties of } \\
\text { vaporized titan layers }\end{array}$ & $\begin{array}{l}\text { Dept. of Physics and } \\
\text { Measurement Technology, } \\
\text { Linköping University }\end{array}$ & $\begin{array}{l}\text { Ingemar } \\
\text { Lundström } \\
\text { Sven-Erik Karlsson } \\
\text { Jan-Eric Sundgren } \\
\text { Birgit Jacobsson } \\
\text { Hans Hentzell } \\
\text { Ulf Helmersson }\end{array}$ \\
\hline $\begin{array}{l}\text { Solid surface in contact with } \\
\text { biofluids }\end{array}$ & $\begin{array}{l}\text { Dept. of Food Technology, } \\
\text { Lund University }\end{array}$ & Kåre Larsson \\
\hline \multirow[t]{2}{*}{$\begin{array}{l}\text { Titanium and titanium } \\
\text { compounds-New types of } \\
\text { bio-friendly surfaces }\end{array}$} & $\begin{array}{l}\text { Dept. of Physics and } \\
\text { Measurement Technology, } \\
\text { Linköping University }\end{array}$ & $\begin{array}{l}\text { Ingemar } \\
\text { Lundström } \\
\text { Jan-Eric Sundgren } \\
\text { Bo Liedberg }\end{array}$ \\
\hline & $\begin{array}{l}\text { Dept. of Applied } \\
\text { Biotechnology, GU }\end{array}$ & Peter Thomsen \\
\hline Cinetics of CVD processes & $\begin{array}{l}\text { Dept. of Chemistry, Uppsala } \\
\text { University }\end{array}$ & $\begin{array}{l}\text { Jan-Otto Carlsson } \\
\text { Mats Boman } \\
\text { Eva Fredriksson } \\
\text { Ulf Jansson }\end{array}$ \\
\hline \multirow{2}{*}{$\begin{array}{l}\text { Surface properties of steel after } \\
\text { mordanting, cold rolling, and } \\
\text { annealing }\end{array}$} & $\begin{array}{l}\text { Institute of Metals Research, } \\
\text { Stockholm }\end{array}$ & $\begin{array}{l}\text { Bengt Johansson } \\
\text { Olle Grinder }\end{array}$ \\
\hline & \multicolumn{2}{|c|}{ (Industrial partners: SSAB, SAAB, Volvo) } \\
\hline $\begin{array}{l}\text { Mechanisms for corrosion and } \\
\text { catalysis }\end{array}$ & Chalmers & $\begin{array}{l}\text { Stig Andersson } \\
\text { Bengt Lundqvist } \\
\text { Ingemar Olefjord } \\
\text { Nils-Gösta } \\
\text { Vannerberg }\end{array}$ \\
\hline $\begin{array}{l}\text { Electrochemical and physical } \\
\text { structure of corroded metal } \\
\text { surfaces }\end{array}$ & $\begin{array}{l}\text { Corrosion Institute (KI), } \\
\text { Stockholm }\end{array}$ & $\begin{array}{l}\text { Christofer Leygraf } \\
\text { Dominique Thierry }\end{array}$ \\
\hline $\begin{array}{l}\text { Structure of microemulsions } \\
\text { Absorption in latex and pigment } \\
\text { dispersions } \\
\text { Solid surfaces: Surface } \\
\text { modification and particle adhesion }\end{array}$ & $\begin{array}{l}\text { Institute of Surface Chemistry } \\
(\mathrm{YKI}) \text {, Stockholm }\end{array}$ & $\begin{array}{l}\text { Per Stenius } \\
\text { Bengt Kronberg } \\
\text { Carl-Gustav } \\
\text { Gölander } \\
\text { Eva Sjöblom }\end{array}$ \\
\hline $\begin{array}{l}\text { Phase equilibria in micro emulsion } \\
\text { system with specific attention to } \\
\text { cleaning }\end{array}$ & $\begin{array}{l}\text { Division of Physical Chemistry, } \\
\text { Lund University }\end{array}$ & $\begin{array}{l}\text { Björn Lindman } \\
\text { Bengt Jönsson }\end{array}$ \\
\hline Educational activities & $\begin{array}{l}\text { Dept. of Physics and } \\
\text { Measurement Technology, } \\
\text { Linköping University }\end{array}$ & Birgit Jacobsson \\
\hline
\end{tabular}

Sources: Ytors fysik och kemi (ref. 50); Report on Visiting Committee on Swedish Research in Physics and Chemistry of Surfaces and Coatings: Arranged by the Engineering Sciences Advisory Board of STU (STUs vetenskapliga råd), STU-information 264-1981 (Stockholm: STU, 1981); Report of Evaluation Committee on Swedish Research in Physics and Chemistry of Coatings, STU-information 3181983 (Stockholm: STU, 1983). 
within the framework for the period I980-1985 was taken by STU management in the summer of 1980. In total, the program budget for the five years amounted to I5 million SEK (roughly US\$3.5 million in I98o dollars). ${ }^{49}$

As seen in Table I, corrosion was the focus of two projects in the program. The project at Chalmers, "Mechanisms for corrosion and catalysis," was a fusion of two initiatives, first the surface physics program developed by the two physics departments at Chalmers in 1978, and second, the project proposal of the departments of inorganic chemistry and metal construction materials on corrosion properties and protection of steel. The fusion was made in collaboration with STU and became a multidisciplinary effort at Chalmers that involved chemists, theoretical and experimental physicists, and materials scientists. ${ }^{50}$ Through this project and its sibling at the Corrosion Institute in Stockholm, STU aimed at enhancing the study of corrosion in Sweden both scientifically and with industrial relevance. ${ }^{51}$

Another area of focus within the framework program was thin film technology, where especially the group around Jan-Eric Sundgren at Linköping University, continuing the work of Stig Hagström, was internationally prominent. Sundgren's own work was partly focused on hard surface coating of tools, but thin film technology had spread at Linköping University, and several groups actively used this generic technology for a variety of purposes. ${ }^{52}$ At STU, competence in thin film technology was secured by the participation of Birgit Jacobsson in the steering group of the program, which also secured the continued access to international networks, not least of course in the United States. The industrial relevance of thin film technology was particularly evident for the Swedish tool manufacturing company Sandvik, which was also represented in the steering group, and whose collaboration with the research group of Jan-Otto Carlsson at the Department of Chemistry in Uppsala also secured a vital academy-industry connection. ${ }^{53}$

49. Weinberger, Nätverksentreprenören (ref. 40), 445-50.

5o. Weinberger Nätverksentreprenören (ref. 40), 444; Ytors fysik och kemi: Resultatsammanställning frän forskning inom STUs ramprogram 1980-85, STU-information 62I-1987 (Stockholm: STU, 1987), 37-50.

5I. Christofer Leygraf, interview with Johan Gribbe, 13 Oct 2015; Ytors fysik och kemi (ref. 50), $5 \mathrm{I}-57$.

52. Sundgren interview (ref. 29); Lundström interview (ref. 48).

53. Bertil Aronsson, interview with Johan Gribbe, 30 Oct 20I5; Jan-Otto Carlsson and Sören Berg, interview with Johan Gribbe, 22 Sep 2015. 
The first in a series of evaluations of the framework program was already undertaken in the fall of 198I by an expert group of British and U.S. industrial research laboratory and funding agency representatives. This evaluation was mostly aimed at the thin film technology part of the program, and although it led to no changes in the structure of the program, the evaluation recommended a tighter collaboration between the two groups with thin film projects, in Uppsala and Linköping. Another evaluation was undertaken in 1982, during the first half of the program, by the very same expert group, and recommended continued funding for all projects except the project at the Institute of Metals Research, Stockholm. ${ }^{54}$

\section{Microelectronics, 1984-1989}

Although the framework programs of STU in the I980s (discussed previously and in the next section) were very important for the growth of materials science in Sweden, they were minuscule in comparison with the microelectronics programs launched by the Swedish government in the same decade. This new area, internationally recognized as a strategically important area of research for Sweden, was also a cross-disciplinary area heavily reliant on advanced technologies, with generic capabilities and with a potential to renew industry in several important branches. ${ }^{55}$ The Swedish National Microelectronics Program (Nationella Mikroelektronikprogrammet, NMP), launched in 1984, had research on semiconductor materials as a key component, and the buildup of infrastructure in Swedish universities within the program became an important basis of further development within materials science as well. ${ }^{56}$

The NMP, preceded by a STU framework program for electronic and electrooptical component technology (1978-1985), was focused on instrumentation and the buildup of research laboratories at the universities and at the Institute of Microwave Technology (IM) in Stockholm, and had several industrial partners. ${ }^{57}$ In 1983-1988, the NMP spent no less than 550 million SEK (approximately US $\$ 70$ million in 1983 dollars), matched by a total of 150 million SEK contributions from industrial firms (approximately US\$2O million in 1983

54. Weinberger, Nätverksentreprenören (ref. 40), 454, 46I-65.

55. Persson, Motsträviga (ref. 39), 210.

56. Nationella mikroelektronikprogrammet: En presentation, STU-information 494-1985 (Stockholm: STU, 1985).

57. Nationellt Mikroelektronikprogram, STU-information 376-1983 (Stockholm: STU, 1983), I9-20. 
dollars). The program was divided into four areas: education, basic research, goal-oriented research, and industrial development. The basic research area was run by NFR and had a clear focus on capacity building in semiconductor materials, an relatively small area in Swedish universities but with some strength particularly in the manufacturing and characterization of semiconductor materials, and the study of surfaces and thin layers, which was where the NMP support was channeled. The lion's share of the funding within the NMP goal-oriented research area in the first four years-in all 40 million SEK (approximately US\$5.2 million in 1983 dollars) — went to the buildup of scientific equipment at Lund University, Linköping University, and Chalmers. ${ }^{58}$ The materials science groups at these three universities had well-established relationships with industrial firms and many connections on the personal level. The activities in Linköping had been developed largely by people from Chalmers and Lund, and both Hermann Grimmeiss, the first professor of solid state physics at Lund University (appointed in 1965), and Bo Monemar, who led the semiconductor physics research in Linköping, had backgrounds in industry. In Lund, Lars Samuelson, a former doctoral student of Bo Monemar, had established a research line in the manufacturing of fast transistors, much with the help of novel instrumentation built up at the university. ${ }^{59}$ At Chalmers and in Linköping, focus was on the manufacturing of semiconductor materials with various techniques, as well as polymer conductors and electrical sensors, at Chalmers under the leadership of Torwald Andersson and Per-Olof Nilsson, and in Linköping under the leadership of William Salaneck and Ingemar Lundström. ${ }^{60}$

The area of goal-oriented research within NMP, run by STU, also had important materials science components. Most of the funding within the area went to research activities in and around the universities, especially at the Institute of Microwave Technology (Institutet för Mikrovågsteknik, IM) whose collaboration with $\mathrm{KTH}$ was prominent, but also at the universities in Uppsala, Lund, and Linköping, and at Chalmers, where technologyintensive research on advanced manufacturing methods for semiconductor materials dominated. ${ }^{61}$ The whole microelectronics program continued until 1989, and made a lasting imprint on Swedish academic natural and technical

58. Nationella mikroelektronikprogrammet (ref. 56), 5-7.

59. Lars Samuelson, interview with Johan Gribbe, I7 Nov 2015.

6o. Materials Research at Chalmers University of Technology: Research Projects in Progress (Göteborg: Chalmers University of Technology, 1984), 29-30; Lundström interview (ref. 48); Nationella mikroelektronikprogrammet (ref. 56), 6.

6I. Nationella mikroelektronikprogrammet (ref. 56), 8. 
sciences in general, and materials science particularly, most of all because it enabled several universities to acquire advanced and expensive equipment for microfabrication and thin film manufacturing and characterization. This way, the NMP set the course also for the future development of several of the core areas of Swedish materials science, including what would become nanoscience and nanotechnology.

\section{“Micronics," 1987-1990}

The direct sequel to the framework program for the physics and chemistry of surfaces was the framework program for "micronics" ("mikronik" in Swedish), a unique term that referred to what was internationally known as microtechnology (analogous to nanotechnology, i.e., on the micro level), and used by STU as a common name for technologies that enabled "the fabrication of components and systems whose functions build on a combination of extremely small geometrically determined structures with various biological, chemical and physical properties." ${ }^{62} \mathrm{~A}$ broad label, microtechnology thus encompassed large parts of surface physics and surface chemistry, but also electronics and micromechanics. The background was an identification of advanced materials as central to many branches of industry, and a consequential ambition to enable the control of materials at the molecular and atomic level so as to achieve an infusion of several parts of industry with entirely new materials with entirely new properties. Crucially important for the identification of microtechnology as a viable area for a framework program was the development of instrumentation, which had opened up opportunities to manufacture materials on the molecular and atomic level on basis of a theoretical understanding of their properties. ${ }^{63}$ It is clear that STU was guided by the recent advances in instrument development in their preparatory work for a new framework program: just as the launch of the framework program for the physics and chemistry of surfaces in 1980 had built strongly on the breakthroughs in ultrahigh-vacuum technology in the 1970s, the launch of the microtechnology program of 1987 was largely motivated by the development of STM and AFM. Large parts of the ensuing microtechnology framework program would be devoted to the use and refinement of the STM in various

62. Mikronik: Projektkatalog för ett tvärvetenskapligt forskningsprogram inom kemi, fysik och biovetenskaperna: Etapp I, STU-information 766-1990 (Stockholm: STU, 1990), I.

63. Ibid., I. 
scientific contexts, most evidently perhaps the project led by Ragnar Erlandsson in Linköping. ${ }^{64}$ The framework program was launched in 1987, and several groups that had been beneficiaries of the framework program for the physics and chemistry of surfaces were also selected for the new program (see Table 2), which created a traceable continuity in the materials science efforts of STU in the I980s, that would also continue into the I99os (see below).

TABLE 2. Projects granted funding within the STU framework program for microtechnology, 1987-1990.

\begin{tabular}{|c|c|c|}
\hline Project name & Project leader(s) & Department, university \\
\hline $\begin{array}{l}\text { Microselective absorption of } \\
\text { biomolecules: Mechanisms, } \\
\text { production, and analysis }\end{array}$ & $\begin{array}{l}\text { Jan-Otto Carlsson } \\
\text { Bo Sundqvist }\end{array}$ & Uppsala University \\
\hline $\begin{array}{l}\text { Theoretical and experimental } \\
\text { studies of microtechnology } \\
\text { structures }\end{array}$ & Arne Rosén & Dept. of Physics, Chalmers \\
\hline $\begin{array}{l}\text { Manufacturing of nanometer } \\
\text { structures }\end{array}$ & $\begin{array}{l}\text { Tord Claeson } \\
\text { Bengt Kasemo } \\
\text { Christina Ullenius }\end{array}$ & $\begin{array}{l}\text { Dept. of Physics, Dept. of } \\
\text { Inorganic Chemistry, Chalmers }\end{array}$ \\
\hline $\begin{array}{l}\text { Microtechnology with small } \\
\text { particle theory }\end{array}$ & Jan-Erik Otterstedt & Dept. of Chemistry, Chalmers \\
\hline Organic thin film physics & $\begin{array}{l}\text { Hans Arwin } \\
\text { Ingemar Lundström }\end{array}$ & $\begin{array}{l}\text { Dept. of Physics and } \\
\text { Measurement Technology, } \\
\text { Linköping University }\end{array}$ \\
\hline $\begin{array}{l}\text { Laser spectroscopic studies of } \\
\text { Langmuir-Blodgett films, } \\
\text { especially Scheibe-Kuhn } \\
\text { aggregates and the Photon- } \\
\text { funnel effect }\end{array}$ & Sten-Eric Lindquist & $\begin{array}{l}\text { Dept. of Physical Chemistry, } \\
\text { Uppsala University }\end{array}$ \\
\hline $\begin{array}{l}\text { Manufacturing and analysis of } \\
\text { sub micron structures with } \\
\text { emphasis on catalysis and } \\
\text { biomaterials }\end{array}$ & Bengt Kasemo & Dept. of Physics, Chalmers \\
\hline $\begin{array}{l}\text { Enzyme-like polymers in } \\
\text { selective organic synthesis }\end{array}$ & Styrbjörn Byström & $\begin{array}{l}\text { Dept. of Organic Chemistry, } \\
\text { KTH }\end{array}$ \\
\hline $\begin{array}{l}\text { Structured polymers through } \\
\text { polymerization in liquid } \\
\text { crystalline phases and micro } \\
\text { emulsions }\end{array}$ & Björn Lindman & $\begin{array}{l}\text { Dept. of Physical Chemistry, } \\
\text { Lund University }\end{array}$ \\
\hline
\end{tabular}


TABLE 2. (continued)

\begin{tabular}{|c|c|c|}
\hline Project name & Project leader(s) & Department, university \\
\hline $\begin{array}{l}\text { Molecular imprints-their } \\
\text { characterization and use in } \\
\text { separation and as sensors }\end{array}$ & Klaus Mosbach & $\begin{array}{l}\text { Dept. of Applied Biochemistry, } \\
\text { Lund University }\end{array}$ \\
\hline Molecular switches & Olof Wennerström & $\begin{array}{l}\text { Dept. of Organic Chemistry, } \\
\text { Chalmers and Dept. of Organic } \\
\text { Chemistry, Umeå University }\end{array}$ \\
\hline $\begin{array}{l}\text { Nanometer size structures for } \\
\text { physics, electronics and } \\
\text { reciprocity with molecules and } \\
\text { biomaterials }\end{array}$ & Lars Samuelson & $\begin{array}{l}\text { Dept. of Physics, Lund } \\
\text { University }\end{array}$ \\
\hline $\begin{array}{l}\text { Undulator light source and x-ray } \\
\text { optics: Submicron } \\
\text { photoelectron microscopy at the } \\
\text { MAX laboratory }\end{array}$ & Anders Flodström & Dept. of Materials Physics, KTH \\
\hline $\begin{array}{l}\text { Electrode structures for } \\
\text { microelectronics and molecular } \\
\text { electronics }\end{array}$ & Olle Inganäs & $\begin{array}{l}\text { Dept. of Physics and } \\
\text { Measurement Technology, } \\
\text { Linköping University }\end{array}$ \\
\hline $\begin{array}{l}\text { Studies of electron transmission } \\
\text { between immobilized proteins } \\
\text { and conducive and semi- } \\
\text { conducive materials }\end{array}$ & Sten-Eric Lindquist & $\begin{array}{l}\text { Dept. of Physical Chemistry, } \\
\text { Uppsala University }\end{array}$ \\
\hline Microtechnology at YKI & Thomas Ahlnäs & $\begin{array}{l}\text { Institute for Surface Chemistry } \\
\text { (YKI) }\end{array}$ \\
\hline $\begin{array}{l}\text { Differential geometry- } \\
\text { Structures and properties of } \\
\text { substances }\end{array}$ & Zoltan Blum & $\begin{array}{l}\text { Dept. of Inorganic Chemistry, } \\
\text { Lund University }\end{array}$ \\
\hline $\begin{array}{l}\text { Multi sensor chips and } \\
\text { chemometrics development }\end{array}$ & $\begin{array}{l}\text { Svante Wold } \\
\text { Ingemar Lundström }\end{array}$ & $\begin{array}{l}\text { Dept of Organic Chemistry, } \\
\text { Umeå University, and Dept. of } \\
\text { Physics and Measurement } \\
\text { Technology, Linköping } \\
\text { University }\end{array}$ \\
\hline $\begin{array}{l}\text { Fabrication of nanometer } \\
\text { structures and investigation of } \\
\text { their properties }\end{array}$ & Tord Claeson & Dept. of Physics, Chalmers \\
\hline Atomic force microscopy (AFM) & Ragnar Erlandsson & $\begin{array}{l}\text { Dept. of Physics and } \\
\text { Measurement Technology, } \\
\text { Linköping University }\end{array}$ \\
\hline $\begin{array}{l}\text { Cromatography and } \\
\text { electrophoresis in thin layers } \\
\text { and films }\end{array}$ & Johan Roeraade & Dept. of Chemistry, KTH \\
\hline $\begin{array}{l}\text { Polymers for electro-optical } \\
\text { information storage }\end{array}$ & Per Flodin & $\begin{array}{l}\text { Dept. of Polymer Technology, } \\
\text { Chalmers }\end{array}$ \\
\hline
\end{tabular}

Source: Mikronik (ref. 62). 
The Materials Consortia, 1990-2000

The discussions within STU regarding the form and function of programs in the area of materials science continued without interruption throughout the I980s, and the area remained a main priority of the agency. The framework programs were key pieces in this strategic work of STU, but they were comparably modest: the microelectronics program discussed above had an annual funding of over IOo million SEK, whereas the framework programs on the physics and chemistry of surfaces and on microtechnology had annual funding envelopes of a mere few million SEK. True, the microelectronics program had some key materials science components, but its main focus was elsewhere. Thus as this program wound down in 1989, a window of opportunity opened for materials science.

Plans for a new nationwide program in materials science and technology, preferably in collaboration with other funding agencies, were drafted at STU during the second half of the I980s. The ambitions were shared by NFR, the research council with governmental mandate to support fundamental research in the natural sciences, and the influential Royal Academy of Engineering Sciences (IVA), both of whom viewed STU as the best-suited actor to orchestrate a wider effort in what they saw as a strategically important area for Sweden. ${ }^{65}$ In 1987 , STU and NFR began working together on a program for materials science consortia. The complementary roles of these two agencies in Swedish research policy caused a win-win situation in their collaboration: STU got access to the scientific competence of the council as well as, importantly, the legitimacy that NFR had in the academic sector, and NFR was able to tap into the resources of STU, which at the time were not only greater but also available for strategic priorities, unlike the NFR money, which was largely tied to regular project funding for disciplinary research in predefined areas. ${ }^{66} \mathrm{An}$ evaluation of Swedish research in condensed matter physics, undertaken on charge by NFR in 1986, had shown that several very promising research groups in materials science in Swedish universities were in need of additional money to be able to continue their activities; most of the governmental appropriations to the universities was line-item funding for existing chairs and not easily available for strategic reprioritization within universities or faculties. ${ }^{67}$ The

65. Persson, Motsträviga (ref. 39), 2I8; Svensk materialutveckling i förnyelse, IVA-meddelande 259 (Stockholm: IVA, 1988).

66. Persson, Motsträviga (ref. 39), 218-22; Weinberger, Nätverksentreprenören (ref. 40), 397ff. 67. International evaluation of condensed matter physics (Lund and Stockholm: NFR, 1986). 
governmental research bill of 1987 noticed this and urged the research funding agencies to make broader investments, citing "difficulties within the university system of creating the new combinations of disciplinary specialties and interdisciplinary research centers necessary for international success" and evidence from abroad that "internationally competitive basic research requires close co-operation between several research groups working within the same research theme," especially in "fields undergoing fast development, requiring broad competence and expensive equipment." ${ }^{8}$ Materials science and technology was mentioned throughout the bill as a prioritized research area of national importance.

In 1989, STU and NFR published a joint plan for a new consortia program and requested funding from the government, and in the spring of 1990, the Swedish parliament granted the program initial funding of 30 million SEK (approximately US\$5 million in 1990 dollars) for the years 199I-1993. The consortia would be cross-disciplinary and formed by a number of existing research groups at Swedish universities and institutes, and funded jointly by STU and NFR. Although the idea originally came from the STU planning unit, the structure of the program was also in part shaped by NFR: the consortia were clearly more oriented toward fundamental academic science than the STU framework programs of the I980s, and the periods of funding were longer (five plus five years), which also signaled an orientation to long-term, fundamental research, the primary mandate of NFR. The research leaders of the consortia were granted the key role of being responsible for the distribution of funding within the consortia, between the participating groups. ${ }^{69}$

The inspiration for this model had come mostly from abroad; IVA had argued for center funding of the type that was popular in both the United Kingdom and the United States, and STU had maintained its contacts with the NSF and the American materials science community, and was able to refer to the successful buildup of cross-disciplinary efforts in this field from the late 1940s and on, which in no small part had been undertaken by the creation of centers with involvement of several research groups and representation from industry. ${ }^{70}$ Scientifically, the consortia program stood on the shoulders of giants both in

68. Regeringens proposition 1986/87:80 om forskning (Swedish governmental bill 1986/87: 8o), 46 .

69. Persson, Motsträviga (ref. 39), 220-2I, 23 I.

70. Stenberg interview (ref. 4I); Mody and Choi, "From materials science" (ref. I), 155-56; STU-perspektiv 1989: Plan och förslag 1990/9I-1992/93, STU-information 738-1989 (Stockholm: STU, 1989): 2I-23. 
a general sense, building on the rapid but broad international progress in materials science in the 1980s, not least by the refinement of instrumentation, and in a specific sense, with the Swedish experience of several prominent research activities establishing themselves at the universities in the 1970s and '8os. STU pointed at both developments in its background material for the consortia program, and emphasized the potential of the field to undergo a further accelerated development, given adequate support from funders. ${ }^{71}$

This analysis of the recent developments and state-of-the-art of materials science became the foundation for the composition of the steering group for the program. The scientific experts who took part in this group were Börje Johansson, one of Sweden's leading materials theorists, Anders Flodström, former coordinator of the synchrotron radiation activities at the national facility MAX-lab in Lund and professor of materials physics at KTH, and Jan-Otto Carlsson who was an inorganic chemist and the primus motor of the thin film activities in Uppsala. The administrators at STU who took part in the steering group were Göran Friborg, Staffan Hjort, and Ingela Agrell. This six-person group was put in charge of evaluating the proposals for consortia, in total 70. In a two-step selection, 20 applicants were first invited to submit a more detailed proposal, and then eleven consortia were finally selected. The criteria for evaluation and selection were aimed at both scientific quality and industrial relevance. $^{72}$

As seen in Table 3, several of the project leaders from the framework programs of the 1980 os also emerged as research leaders within the consortia, as well as the three expert members of the steering group.

The program ran from 1990 to 2000 , and because of its size and concentration to a smaller number of groups, it meant a significant addition of funding for the participating researchers and quite some leeway within the consortia in using the funding. Each consortium received an average of four million SEK annually_compared with the annual funding within the previous framework programs, where the annual funding for each group averaged 300,00o SEK. In total, the program allocated 390 million SEK during ten years (US\$4 million in 2000 dollars) until it was phased out in 200o. In the same period, the Swedish National Council for Planning and Coordination of Research (Forskningsrådsnämnden, FRN) granted several

71. Materialteknik: Underlag och förslag till insatser inom ett nationellt program, STUinformation 749-1989 (Stockholm: STU, 1989), 23-24.

72. Persson, Motsträviga (ref. 39), 223-24. 
TABLE 3. Materials science consortia funded by STU/NFR, 1990-2000.

\begin{tabular}{|c|c|c|c|}
\hline Consortium & Research leader(s) & Universities & $\begin{array}{l}\text { Phased } \\
\text { out (year) }\end{array}$ \\
\hline $\begin{array}{l}\text { Materials with unique } \\
\text { functional properties }\end{array}$ & $\begin{array}{l}\text { Olle Wijk } \\
\text { Jan-Eric Ståhl } \\
\text { Roger Wäppling }\end{array}$ & $\begin{array}{l}\text { KTH } \\
\text { Lund University } \\
\text { Uppsala University }\end{array}$ & 1995/96 \\
\hline $\begin{array}{l}\text { The Ångström consortium } \\
\text { for thin film processing }\end{array}$ & $\begin{array}{l}\text { Jan-Otto Carlsson } \\
\text { Sören Berg }\end{array}$ & Uppsala University & 2000 \\
\hline $\begin{array}{l}\text { Single crystal layers- } \\
\text { Growth and artificial } \\
\text { structures }\end{array}$ & $\begin{array}{l}\text { Jan-Eric Sundgren } \\
\text { Lars Hultman }\end{array}$ & $\begin{array}{l}\text { Linköping } \\
\text { University }\end{array}$ & 2000 \\
\hline $\begin{array}{l}\text { Nanometer structures- } \\
\text { Manufacturing, } \\
\text { characterization, and } \\
\text { applications }\end{array}$ & Lars Samuelson & Lund University & 2000 \\
\hline $\begin{array}{l}\text { Surface- and thin film } \\
\text { properties of ceramic } \\
\text { layers-Metal oxid surface } \\
\text { structures }\end{array}$ & Jan Paul & KTH & 1995/96 \\
\hline $\begin{array}{l}\text { Clusters and ultra fine } \\
\text { particles }\end{array}$ & $\begin{array}{l}\text { Arne Rosén } \\
\text { Mamoun Muhammed } \\
\text { Nils Mårtensson }\end{array}$ & $\begin{array}{l}\text { Chalmers } \\
\text { KTH } \\
\text { Uppsala University }\end{array}$ & 2000 \\
\hline $\begin{array}{l}\text { Interfacial interactions in } \\
\text { polymeric systems }\end{array}$ & Thomas Hjertberg & $\begin{array}{l}\text { Chalmers } \\
\text { Lund University }\end{array}$ & 1995/96 \\
\hline $\begin{array}{l}\text { Biomaterials-Surface } \\
\text { modification, surface } \\
\text { analysis, model studies, new } \\
\text { materials, macromolecules, } \\
\text { and surfaces }\end{array}$ & $\begin{array}{l}\text { Bengt Kasemo } \\
\text { Ingemar Lundström }\end{array}$ & $\begin{array}{l}\text { Chalmers } \\
\text { Linköping University }\end{array}$ & 2000 \\
\hline $\begin{array}{l}\text { Theory-based expert } \\
\text { systems for materials } \\
\text { configuration }\end{array}$ & $\begin{array}{l}\text { Bengt Lundqvist } \\
\text { Göran Grimvall } \\
\text { Börje Johansson }\end{array}$ & $\begin{array}{l}\text { Chalmers } \\
\text { KTH } \\
\text { Uppsala University }\end{array}$ & 2000 \\
\hline $\begin{array}{l}\text { Computer-supported } \\
\text { materials and process } \\
\text { development }\end{array}$ & Bo Sundman & KTH & 2000 \\
\hline $\begin{array}{l}\text { High-temperature } \\
\text { superconducting materials }\end{array}$ & Tord Claeson & Chalmers & 2000 \\
\hline
\end{tabular}

Source: Tvärvetenskapliga konsortier (ref. 76). 
million SEK in additional funding to the materials consortia, specifically for instrumentation. ${ }^{73}$

The consortia were evaluated four times by an international panel; a I99I evaluation focused on the structures of the consortia, whereas the 1992, 1995, and 2002 evaluations focused on results. Three consortia were phased out after the 1995 evaluation, and the program was carried on with eight consortia (see Table 3). In 1997, the newly created Swedish Foundation for Strategic Research (Stiftelsen för Strategisk Forskning, SSF) took over the program from STU, but made no noticeable changes to its structure. ${ }^{74}$

It is important to note that the materials science consortia program was the first broad and comprehensive Swedish funding program in advanced materials science and materials technology, and that this therefore was the first time that the very broad collection of scientific activities in Swedish universities that can be considered "materials science" were brought together in an inclusive but well-defined effort. Meanwhile, of course, the program was linked to previous funding programs in the I980s: most of the participating research groups had also received funding through the framework programs on the physics and chemistry of surfaces, microtechnology, or the microelectronics program.

The consortia program was an important factor behind the development of several leading research environments in materials science in Swedish universities in the 1990s and later, in most cases around laboratories very well equipped with advanced instrumentation. This aspect-the agglomeration of research activities around advanced instrumentation and laboratory environments - proved important as the I990s proceeded: those consortia that were geographically dispersed and included groups from several universities were less successful, and three of them were also phased out after five years, whereas those that were concentrated to one university and a central lab environment became the most successful. All of the consortia produced research results and breakthroughs of high international standard, but when it comes to the longterm, profound impacts on the scientific side, three consortia especially stand out. First, the nanometer consortium at Lund University, built around professor Lars Samuelson but with important participation by professors Hermann Grimmeiss and Pär Omling, and with ties to the national synchrotron radiation source MAX-lab, which continued its activities after the phasing out

73. Evaluation of the Programme for Interdisciplinary Materials Research Consortia: Main Report (Stockholm, 2002), 7, 53.

74. Ibid., 5, 27, 29. 
of the program in 2000 and obtained several different program grants within the various excellence funding programs launched in Sweden in 2005 and after. ${ }^{75}$ Second, the thin film research activities in Linköping, led by Jan-Eric Sundgren, who had been appointed to a newly created professorship in 1990. This consortium formed the basis for a very strong development of materials science at Linköping University well into the twenty-first century. ${ }^{76}$ Third, the consortium with focus on biomaterials, formed by Ingemar Lundström in Linköping and Bengt Kasemo at Chalmers, whose activities soon expanded beyond the framework of the consortium and were successful in the biomaterials funding program by the newly created SSF in $1996 .{ }^{77}$ After the consortia program was phased out in 2000, the research groups within these three consortia, and several of the others, received continued support from the sequel programs and other strategic research funding efforts in Sweden.

\section{Further Funding Programs in the 1990s and Beyond}

In 199I, STU was merged with the Swedish National Energy Administration and the Swedish National Industry Administration to form the new Swedish Business Development Agency (Närings- och Teknikutvecklingsverket, NUTEK), which took over the materials consortia program and launched new similar (but larger) funding programs with closer connection to industrial applications of $\mathrm{R} \& \mathrm{D} .{ }^{78}$ One of these was the competence centers program, based in part on the experiences of the materials consortia program but with a clearer demand for industrial participation and with each competence center based at a single university. The focus of the program was much broader than that of the materials consortia program, and included energy, transport, and environmental technology, production and process technology, biotechnology and biomedical technology. and information technology. Hence, it had no explicit focus on materials

75. Fredrik Melander, Lokal forskningspolitik: Institutionell dynamik och organisatorisk omvandling vid Lunds universitet 1980-2005 (Lund: Lund University Press, 2006), 216; Samuelson interview (ref. 59).

76. Sundgren interview (ref. 29); Flodström interview (ref. 29); Tvärvetenskapliga konsortier inom materialvetenskap och materialteknik, STU-information 748-1989 (Stockholm: STU, 1989); Ingela Agrell, interview with Johan Gribbe, I Oct 20I5.

77. Kasemo interview (ref. 47); Lundström interview (ref. 48); Agrell interview (ref. 76); Eugenia Perez Vico, "An in-depth study of direct and indirect impacts from the research of a physics professor," Science and Public Policy 4I (20I4): 70I-I9.

78. Persson, Motsträviga (ref. 39), 233-40; Mats Benner, Kontrovers och konsensus: Vetenskap och politik i svenskt 1990-tal (Stockholm: Nya Doxa, 200I): 56, 69, I07. 
science, but nonetheless many materials science activities could be incorporated into them. ${ }^{79}$ Several of the 29 competence centers that received funding, commencing in 1995, were lead by scientists who were also active in the materials consortia, most notably among them Bengt Kasemo at Chalmers, who set up a center for catalysis in collaboration with Volvo and Saab, among others, and Ingemar Lundström in Linköping, who established the sensor technologies center in collaboration with EKA Chemicals and Pharmacia. ${ }^{80}$

Other funding programs, launched by the research councils and other funding bodies (including SSF), also came to benefit Swedish materials scientists, especially those with established groups, vital (international) networks, and a firm anchoring in the academic system. Bengt Kasemo was one of them; Lars Samuelson in Lund, another. ${ }^{81}$

Generally, the Swedish public research funding system underwent a transformation in a strategic direction in the 1990s, and several funding programs aimed at supporting and cultivating strategically important research groups and environments succeeded each other. In all these, center funding and grants were awarded to materials scientists at the various universities across Sweden, most notably of course Linköping, Lund, Chalmers, and KTH in Stockholm, many of which had been leaders of previous projects and consortia (as discussed previously). The trend culminated around 2008 when the government announced a major investment in what would be called the strategic research areas (SRAs) — twenty areas identified by the government as especially important for the future competitiveness of the Swedish economy, and endowed with a total of 2.66 billion SEK (US $\$ 400$ million in 2008 dollars) to be distributed to a number of research environments over five years. ${ }^{82}$ Four centers in materials science (including nanotechnology), at the universities in Lund and Linköping, and at Chalmers, shared 328 million SEK (US\$50 million in 2008 dollars) over five years (2010-20I4). ${ }^{83}$ The continuity provided by the sequence of grants obtained by these and other research environments is quite clear and speaks to the importance of funding agencies and their strategically oriented efforts for the

79. Staffan Hjorth, The NUTEK Competence Centre Programme (Stockholm, 200o).

8o. Kasemo interview (ref. 47); Hjorth, NUTEK (ref. 86).

8I. Mats Benner and Bo Persson, "Forskningssamverkan i akademisk form," in Det nya forskningslandskapet, ed. Ulf Sandström (Stockholm: Nya Doxa, 200I), I69.

82. Olof Hallonsten and Charlotte Silander, "Commissioning the University of Excellence: Swedish research policy and new public research funding programmes," Quality in Higher Education I8, no. 3 (2012): 367-8I, on 376.

83. Benner, Kunskapsnation (ref. I5), 302-06, 314-24. 
buildup of durable activities in a cross-disciplinary research field such as materials science, in a small country like Sweden.

\section{CONCLUDING DISCUSSION}

\section{Materials Science in Sweden Today}

Ten years into the current century, research in materials science in Sweden was still a field populated by university research groups at departments of physics and chemistry (at the traditionally organized universities), and some more application-oriented departments (at the technical universities). Although several professors of materials science and similar fields exist, most of the key people of the materials consortia and beyond, identified in the previous section, have professorships in different areas, such as semiconductor electronics (Lars Samuelson), condensed matter theory (Börje Johansson), chemical physics (Bengt Kasemo), thin film physics (Jan-Eric Sundgren), inorganic chemistry (Jan-Otto Carlsson), and applied physics (Ingemar Lundström). The state of this area in Sweden some five to ten years ago is therefore better illustrated by the way in which the various activities grouped themselves in the wake of the launch of the unprecedentedly large SRA program by the Swedish government in its 2008 research bill (see previous section). The proposals that were submitted for support within this program give a good picture of how the many disparate activities in materials science in Swedish universities in the I970s, '8os and '9os had evolved and what their strengths and weaknesses were.

Uppsala University and Lund University collaborated on one joint application, building on their natural common point of interest, the Swedish national synchrotron radiation facility MAX-lab, which had been developed gradually in Lund since the late I970s and whose scientific user base was long dominated by the Uppsala physics department. ${ }^{84}$ This strong involvement in MAX-lab by Uppsala physicists can be seen as a natural continuation of the electron spectroscopy tradition in Uppsala that dates back several decades (as discussed previously), and the joint competence of the Lund and Uppsala universities in analysis and characterization of materials therefore became the central theme of this application. The other proposal from Lund University, with Lars Samuelson as principal investigator (see above), was mainly a continuation and development of the nanometer consortium, which had been

84. Hallonsten, "Growing Big Science" (ref. 28). 
active since the end of the 1980 os. The proposal from Linköping University built strongly on the surface and thin film technology activities, with an even longer tradition that dates back to the 1970s (discussed previously). The technical universities KTH in Stockholm and Chalmers in Gothenburg, where a wider variety of activities in materials science had flourished for several decades, had a more difficult time putting together convincingly focused and coherent applications. The international evaluations of the proposals singled out the nanotechnology initiatives in Lund and at Chalmers, and the materials science proposal from Linköping, as the strongest and most worthy of support. The KTH proposal was criticized for not being clear enough in its focus, and the LundUppsala proposal for too strong an emphasis on analysis and characterization. ${ }^{85}$

This outcome reflects the long-term pattern of the growth of materials science in Swedish universities as chronicled throughout this article. At Chalmers and in Linköping and Lund, materials science grew out of strong disciplinary traditions in solid state physics and surface physics, with important international influences introduced by individuals who actively sought them during their formative years as postdocs and subsequently introduced them in their universities as they took up professorships. This inflow of international (mostly U.S.) experiences occurred especially in the I970s, which means that it provided solid ground for the expansion of the 1980s and 1990s, fueled by the new funding programs of STU and NFR. The most evident case is Linköping, where talent was also brought in from Chalmers and Lund in the buildup of activities in the I970s and on. Generally, this means that Linköping, Lund, and Chalmers were able to develop strong research environments in the new materials science that had grown strong not least in the United States in the I970s, whereas the other big universities rather remained true to their older disciplinary traditions. Uppsala quite understandably chose to cherish their Nobel Prize-winning electron spectroscopy tradition, and KTH continued to cultivate their metallurgy activities with roots that go similarly far back.

\section{Instrumentation, Funding, and Individuals}

The introductory sections of this article launched three complementary explanatory models for the history of the emergence and growth of materials science in Sweden, which have theoretical connection to the sociology of

85. Rekommenderad fördelning av medel till strategiska forskningsområden. Bilaga 3: Expertpanelernas slutgiltiga yttranden per område. Swedish Research Council, 2009. 
science and offer useful conceptual tools that go beyond classic views of theory as the primary driver behind the emergence and growth of scientific fields. Two of these were the role of instrumentation and the role of entrepreneurially minded individuals. Developments in spectroscopy and microscopy during the twentieth century opened vast new opportunities for several applications of the study of materials, and the very broad and varied collection of instruments and techniques that these developments produced provided several disciplinary specialties with new tools for advancement. In Sweden, as the chronicle in previous sections show, it was very much through the introduction of new technologies and methods that new materials science research activities could establish themselves at Swedish universities. Behind the investments in advanced materials in the 1980s was a swift technological development in surface science, ultimately drawing strength from the advances in ultrahighvacuum technology in the 1960s and '70s, and those research environments that became durably successful throughout the 1980 s, ' 90 s, and 2000 s were all located and concentrated to well-equipped laboratories shared by several university departments.

But the role of individuals, pursuing their research ambitions in university settings, or promoting new research areas in funding agencies and the research policy system, is also evidently strong in the above chronicle and analysis. Early on, in the 1950s and '6os, pioneers brought their experiences from research stays in the United States and built new research environments on them (Mats Hillert, Bengt Rånby). In the 1970s, as the new developments started to take root, administrators and policymakers within funding agencies (especially STU) worked purposefully, also with inspiration especially from the United States, to launch new types of funding programs to strengthen Swedish materials science (Sigvard Tomner, Björn Englund, Paul Forsgren). In the I97os, '8os, and on, a new generation of Swedish materials scientists established their research activities largely on the basis of new opportunities in instrumentation and funding, and with strong influence from the United States, but doubtlessly also out of personal ambition and skill (first Stig Hagström and Stig Lundqvist, later Bengt Kasemo, Birgit Jacobsson, Jan-Otto Carlsson, Anders Flodström, Lars Samuelson, Jan-Eric Sundgren, and Ingemar Lundström).

But for materials science in Sweden to take off, it seems the role of new funding programs was the most important. The first STU programs of the I980s were inspired by U.S. counterparts and enabled entrepreneurially minded individuals with their knowledge in advanced new instrumentation to develop research activities at universities in spite of sometimes inert and 
conservative disciplinary compartmentalization. In a next step, the continuity provided by the consecutive STU programs, emphasized in the chronicle and seen in Tables $\mathrm{I}-3$, countered the heterogeneity of disciplinary roots and the use of instrumentation and techniques, and functioned as a cohesive force. It is important to note that while the scientists who spent time in the United States in the 1950s, '6os, and '7os came back and established new materials science activities at Swedish universities around new instruments and techniques, they were highly specialized and therefore a strongly heterogeneous group, and their import from the United States comprised of a rather fragmented selection of the broader North American field of materials science. Swedish materials science became a coherent field of science (though still cross-disciplinary and varied in its uses of experimental techniques) only as governmental funding programs gathered the many disparate entities under one wide umbrella and gave them a common strategic importance for the long-term competitiveness of Swedish industry. Here, the three explanatory models converge: among many things, third-party funding importantly enabled the entrepreneurially minded scientists to invest in advanced instrumentation that kept their research groups internationally competitive for decades to come. Besides the STU programs, the role of regular project funding from NFR also deserves mentioning, as it contributed to enable a new generation of scientists to develop their own research activities at the universities with external funding and with some independence from the influential holders of chairs in traditional disciplines.

To this line of analysis should be added the seemingly strong sense of mutual purpose and collaboration among scientists, funding organizations, and politicians, which probably helped to build cohesion among diversified scientific activities. The materials consortia program was in a sense the crown of this collective (or corporatist) achievement. In a wider context, it should be noted that the funding programs for materials science also paved the way for the new strategic direction of Swedish research policy in the I99os and after, which produced the several excellence center funding programs by various agencies. Consequently, some research groups that had benefitted from the STU funding programs in the 1980s and '9os also became very successful with allocations through the governmental SRA program.

Thus the process of institutional change, whereby the essentially intact Swedish university system was infused with a new area of science with strategic importance for Swedish industry, was driven by instrumentation and by entrepreneurially minded individuals (under some influence from the United States), 
but most of all by the efforts of funding agencies that identified a potential and acted to fulfill it. A varied group of actors, subfields, and institutions played different roles at various stages in this process. By its analysis, this article therefore offers deeper knowledge about a previously understudied process of field formation and expansion in science, in coherence with renewed science policy priorities and structural transformations in science and society, under the specific circumstances of the Swedish research system in the Cold War era.

\section{ACKNOWLEDGEMENTS}

We are grateful to Vinnova for supporting the research on which this article is based. We would also like to thank the noted interviewees for their kind generosity with time and information. The work on the article was also made possible by a postdoctoral scholarship from the PhD physicist Ragnar Holm Foundation at the KTH Royal Institute of Technology, Stockholm. 